\title{
Multiple sclerosis and varicella zoster virus infection: A review
}

\author{
R. A. MARRIE ${ }^{1}$ AND C. WOLFSON ${ }^{2 *}$ \\ ${ }^{1}$ Montreal Neurological Institute 3801 rue Universite, Montreal, Quebec H3A 2 B4 \\ ${ }^{2}$ Department of Epidemiology and Biostatistics, McGill University and Centre for Clinical Epidemiology and \\ Community Studies, Jewish General Hospital, 3755 Chemin de la Cote Ste Catherine, Montreal, \\ Quebec, H3T 1E2
}

(Accepted 20 May 2001)

\section{SUMMARY}

We have evaluated the epidemiological evidence for an aetiological role of varicella zoster virus (VZV) infection in the development of multiple sclerosis (MS). A MEDLINE search of the English language literature for 1965-99 identified 40 studies. These studies were categorized as seroepidemiological (13), case-control (23), historical cohort (2) or ecological (2). One study used both case-control and historical cohort methodologies. Studies were then classified according to methodological rigour, using criteria derived from published guidelines for the epidemiological study of MS. There was a large variability in the quality of evidence. The five studies with the best methodology failed to show an increased risk of MS associated with varicella or zoster infections. At the present time there is insufficient evidence to support an important aetiological role of VZV infection in the development of MS.

\section{INTRODUCTION}

Multiple sclerosis (MS) is an inflammatory demyelinating disease of the central nervous system (CNS) typically affecting young and middle-aged adults. A disorder of cell-mediated immunity is postulated, but the underlying aetiology remains unknown. Recently, a multifactorial aetiology was proposed, in which multiple environmental factors act together in a genetically susceptible individual to cause the disease [1]. Geographical and temporal variation in incidence and prevalence, and an apparent age-dependent change in disease risk with migration, support an aetiological role for environmental factors [2].

\footnotetext{
* Author for correspondence: Centre for Clinical Epidemiology and Community Studies, Sir Mortimer B. Davis-Jewish General Hospital, Rm A114, 3755 Chemin de la Cote Ste Catherine, Montreal, Quebec, H3T 1E2.
}

Infection is touted as a potential aetiological agent. Animal models of virally-mediated CNS demyelination exist, the mechanisms of which are unknown [3]. Viruses of the herpesvirus family are of interest because of their neurotropism, ubiquitous nature, and tendency to produce latent, recurrent infections [4]. Varicella zoster virus (VZV) is the herpesvirus that causes varicella (chickenpox) and zoster, representing primary infection and reactivation, respectively. By the age of 15 years, $95 \%$ of individuals in developed countries have acquired the infection [5].

Nasopharyngeal infection is followed by viraemia and then by the appearance of VZV-containing disseminated cutaneous vesicles [6]. Retrograde transport of the virus to trigeminal and dorsal root ganglion sensory neurons is followed by development of latent infection at these sites. Reactivation of the disease, as zoster, occurs in $1 \%$ of the general population per year [6]. Associated CNS complications of varicella 
Table 1. Criteria used for rating of studies

\begin{tabular}{|c|c|c|c|c|}
\hline $\begin{array}{l}\text { Study } \\
\text { rating }\end{array}$ & Seroepidemiological & Case-control & Historical cohort & Ecological \\
\hline A & $\begin{array}{l}\text { - Clearly described } \\
\text { case definition } \\
\text { including reference } \\
\text { to established } \\
\text { criteria. } \\
\text { - Controls selected } \\
\text { from an a priori } \\
\text { defined study base. } \\
\text { - Laboratory } \\
\text { investigators blinded } \\
\text { to subject status. } \\
\text { - Statistical analysis } \\
\text { specified and appropriate. }\end{array}$ & $\begin{array}{l}\text { - Use of incident cases. } \\
\text { - Clearly described case definition. } \\
\text { - Controls selected } \\
\text { from an a priori } \\
\text { defined study base. } \\
\text { - Exposure ascertainment methods } \\
\text { with interviewers blinded to } \\
\text { subject status/hypotheses. } \\
\text { - Exposure ascertainment described, } \\
\text { standardized for cases and } \\
\text { controls. } \\
\text { - Confirmatory source for recalled data. } \\
\text { - Inclusion of an aetiologically } \\
\text { relevant time period. } \\
\text { - Statistical analysis specified and } \\
\text { appropriate. }\end{array}$ & $\begin{array}{l}\text { - Clearly defined cohort. } \\
\text { - Exposure of interest } \\
\text { defined. } \\
\text { - Clearly described case } \\
\text { definition. } \\
\text { - Statistical analysis } \\
\text { estimating relative risk. }\end{array}$ & $\begin{array}{l}\text { - Use of completely assessed } \\
\text { incidence or prevalence } \\
\text { material with } \\
\text { subclassification by } \\
\text { childhood residence. } \\
\text { - Disease rates across differing } \\
\text { geographical regions } \\
\text { determined by uniform methodology } \\
\text { - Adjustment for confounding } \\
\text { variables such as age. } \\
\text { - Selection of an appropriate } \\
\text { time frame between exposure } \\
\text { and disease. } \\
\text { - Calculation of correlation } \\
\text { coefficient with confidence } \\
\text { interval. }\end{array}$ \\
\hline B & $\begin{array}{l}\text { - Clear definitions of } \\
\text { cases and controls } \\
\text { not reported. } \\
\text { - Blinding not } \\
\text { reported/absent. } \\
\text { - Statistical analysis } \\
\text { unspecified. }\end{array}$ & $\begin{array}{l}\text { - Clear definitions of cases and } \\
\text { controls but using prevalent cases. } \\
\text { - Otherwise meeting criteria of A. }\end{array}$ & $\begin{array}{l}\text { - Not meeting criteria of } \\
\text { A. }\end{array}$ & $\begin{array}{l}\text { Disease occurrence measured } \\
\text { by incidence rate only. } \\
\text { - Non-uniform methods used } \\
\text { to obtain disease rates. } \\
\text { - Failure to consider } \\
\text { confounding variables such } \\
\text { as age. } \\
\text { - Failure to calculate } \\
\text { confidence interval for } \\
\text { correlation coefficient. } \\
\text { - Failure to select an } \\
\text { appropriate time frame } \\
\text { between exposure and } \\
\text { disease. }\end{array}$ \\
\hline
\end{tabular}

d study base.

investigators blinded

to subject status.

Statistical analysis

appropriate.

cases and controls

tatistical analysi

unspecified. 


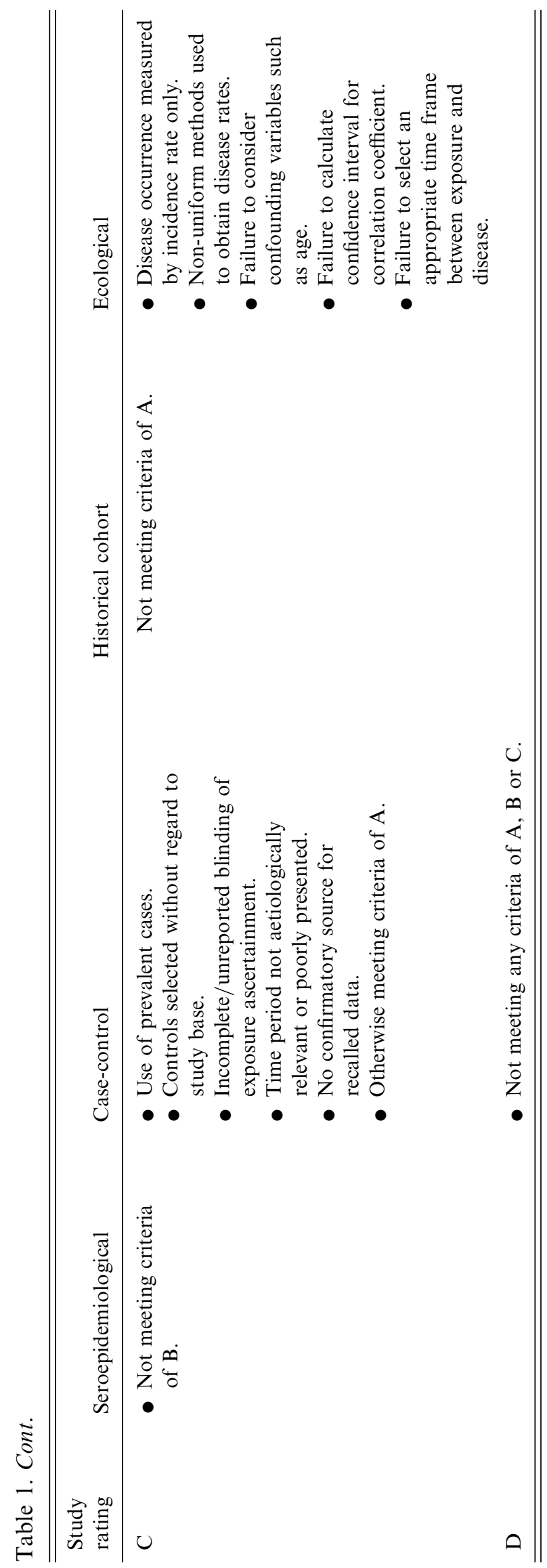

are uncommon, with an observed incidence of less than $1 \%$ [5]. These include cerebellar ataxia, generalized meningoencephalitis, transverse myelitis, aseptic meningitis and Reye's syndrome [5]. Varicella zoster virus has been examined as a potential aetiologic agent in MS in numerous studies. In this article we evaluate the epidemiological evidence for an aetiologic role of VZV in MS.

\section{METHODS}

A MEDLINE search of the English language literature (1965-99) was conducted with subject headings 'multiple sclerosis' and 'varicella' or 'herpes zoster' or 'chickenpox' or 'shingles' or 'infection' or 'casecontrol' or 'cohort' or 'seroepidemiol"' or 'risk'. Bibliographies of all articles retrieved were searched for additional articles. Studies were categorized by design into four groups, seroepidemiological, casecontrol, historical cohort and ecological studies. Only case series, case reports and reviews were excluded as we wished to have a broad view of the evidence available. Ratings of methodological rigour were assigned by one of us (RAM) using criteria derived from published guidelines for the epidemiological study of MS [7-9] (Table 1). There were no previously published guidelines for the evaluation of seroepidemiological studies in MS so these were created for this review using the basic principles of the other guidelines. In each category the criteria for a rating of 'A' were those considered to characterize an ideal study. The lowest rating assigned usually indicated a study lacking all of the ideal characteristics needed for an 'A' rating. Ratings between the highest and lowest ratings identified studies with some but not all of these ideal characteristics. Where necessary for complete evaluation of a study, any prior publications referenced were retrieved. We separately considered the evidence concerning frequency of infection, the age at which infection occurred, and antibody studies in serum and CSF.

\section{RESULTS}

Electronic and hand searches identified a total of 41 published papers. There were 13 seroepidemiological, 2 ecological, 2 historical cohort and 24 case-control studies. Out of these 41 papers, 2 were published twice and therefore each duplicate publication counted as one study, and a third included both a case-control 
Table 2. Case-control studies

\begin{tabular}{|c|c|c|c|c|c|c|}
\hline Author (year) & Number cases & $\begin{array}{l}\text { Number } \\
\text { controls }\end{array}$ & $\begin{array}{l}\text { Result**: freq infection } \\
\text { and seroprevalence }\end{array}$ & $\begin{array}{l}\text { Results: age at } \\
\text { infection }\end{array}$ & Design issues & Rating \\
\hline $\begin{array}{l}\text { Italian MS Study } \\
\text { Group (1989) } \\
\text { [13] }\end{array}$ & 318 incident & 1975 & $\begin{array}{l}\text { No difference in varicella } \\
\mathrm{OR}=0 \cdot 85(0 \cdot 64-1 \cdot 12) \text {, or } \\
\text { zoster } 1 \cdot 19(0 \cdot 77-1 \cdot 85) \\
\text { frequency }\end{array}$ & & & A \\
\hline $\begin{array}{l}\text { Casetta } \\
\text { (1994) [14] }\end{array}$ & 104 prevalent & 150 & $\begin{array}{l}\text { No difference } \\
\text { in frequency of varicella }\end{array}$ & $\begin{array}{l}\text { No difference in } \\
\text { varicella over age } 5 \mathrm{yr} \\
\mathrm{OR}=0.9(0.54-1.64)\end{array}$ & Prevalent cases. & B \\
\hline Gusev (1996) [15] & 155 prevalent & 169 & $\begin{array}{l}\text { No difference in varicella } \\
\text { frequency } \mathrm{OR}=1.00(0.64-1.52)\end{array}$ & $\begin{array}{l}\text { No difference in } \\
\text { varicella after age } \\
15 \mathrm{yr} \\
\mathrm{OR}=0.33(0.01-8.08)\end{array}$ & Prevalent cases & B \\
\hline Alter (1968) [16] & 36 prevalent & 72 & $\begin{array}{l}\text { No difference in } \\
\text { frequency of varicella } \\
(\mathrm{OR}=1.36) \text { or zoster } \\
(\mathrm{OR}=0.65)\end{array}$ & & $\begin{array}{l}\text { Unblinded data collection. } \\
\text { Prevalent cases. Lack of } \\
\text { information on selection of } \\
\text { subjects }\end{array}$ & $\mathrm{C}$ \\
\hline Bansil (1997) [17] & 156 prevalent & 147 & $\begin{array}{l}\text { No difference in } \\
\text { varicella frequency, } \\
\mathrm{OR}=0.8(P=0.49)\end{array}$ & $\begin{array}{l}\text { No difference in } \\
\text { age at infection. }\end{array}$ & $\begin{array}{l}\text { Prevalent cases. Lack of } \\
\text { information on selection of } \\
\text { cases and controls }\end{array}$ & $\mathrm{C}$ \\
\hline Beebe (1969) [10] & 379 prevalent & 379 & $\begin{array}{l}\text { No zoster cases in either } \\
\text { group }\end{array}$ & & $\begin{array}{l}\text { Prevalent cases. No } \\
\text { diagnostic criteria. Lack of } \\
\text { information on selection } \\
\text { of subjects. Blinding } \\
\text { not reported. }\end{array}$ & $\mathrm{C}$ \\
\hline Berr (1989) [18] & 63 prevalent & 63 & $\begin{array}{l}\text { No difference in frequency } \\
\text { of varicella } \\
\text { Zoster more frequent } \\
\text { among cases, } \boldsymbol{P}<\mathbf{0 . 0 5}\end{array}$ & $\begin{array}{l}\text { Tendency varicella } \\
\text { at later ages }\end{array}$ & $\begin{array}{l}\text { Prevalent cases. Unblinded data } \\
\text { collection. Lack of information } \\
\text { on selection of subjects. }\end{array}$ & $\mathrm{C}$ \\
\hline Cendrowski (1969) [19] & 300 prevalent & 300 & $\begin{array}{l}\text { No difference in } \\
\text { varicella frequency; } \\
\text { Zoster less frequent, } \\
P<0.01\end{array}$ & & $\begin{array}{l}\text { Prevalent cases. Poor } \\
\text { diagnostic criteria. More } \\
\text { controls older and male. } \\
\text { Blinding not reported. }\end{array}$ & $\mathrm{C}$ \\
\hline Currier (1974) [20] & 60 prevalent & 60 & $\begin{array}{l}\text { No difference in } \\
\text { frequency of varicella or } \\
\text { zoster }\end{array}$ & & $\begin{array}{l}\text { Prevalent cases. Blinding not } \\
\text { reported. Lack of information } \\
\text { on selection of subjects. }\end{array}$ & $\mathrm{C}$ \\
\hline Gronning (1993) [21] & 155 prevalent & 200 & $\begin{array}{l}\text { No difference in frequency of } \\
\text { varicella } \mathrm{OR}=1 \cdot 1\end{array}$ & $\begin{array}{l}\text { No difference in age at varicella, } \\
P=0.47(7.2 \mathrm{yr} \text { vs. } 7.1 \mathrm{yr}) .\end{array}$ & $\begin{array}{l}\text { Prevalent cases. Unblinded } \\
\text { data collection. }\end{array}$ & $\mathrm{C}$ \\
\hline Gudmundsdottir (1979) [38] & 42 prevalent & 42 & $\begin{array}{l}\text { No difference in seroprevalence } \\
\text { of varicella antibodies; } \\
\text { or in serum } \\
\text { titers. }\end{array}$ & & Prevalent cases. Blinding not reported. & $\mathrm{C}$ \\
\hline Haile (1982) [22] & 72 prevalent & 72 & $\begin{array}{l}\text { No difference in varicella frequency } \\
\mathrm{OR}=1 \cdot 13(0 \cdot 57-2 \cdot 24)\end{array}$ & & $\begin{array}{l}\text { Prevalent cases. Questionnaire use } \\
\text { unblinded. }\end{array}$ & $\mathrm{C}$ \\
\hline Hopkins (1991) [24] & 18 prevalent & 61 & No difference in varicella frequency & & Prevalent cases. Blinding not reported. & $\mathrm{C}$ \\
\hline Kurtzke (1997) [25] & 21 prevalent & 187 & No difference in varicella frequency. & & Prevalent cases. Blinding not reported. & $\mathrm{C}$ \\
\hline Panelius (1969) [11] & 146 prevalent & 146 & $\begin{array}{l}\text { No difference in varicella or zoster } \\
\text { frequency, } P>0.05\end{array}$ & & Unblinded data collection. Prevalent cases. & $\mathrm{C}$ \\
\hline Panelius (1970) [12] & 229 prevalent & 391 & $\begin{array}{l}\text { No difference in varicella or zoster } \\
\text { frequency }\end{array}$ & & $\begin{array}{l}\text { Blinding not reported } \\
\text { for interview. Prevalent cases. }\end{array}$ & $\mathrm{C}$ \\
\hline Poskanzer (1980) [33] & 77 prevalent & 154 & & No difference in age at varicella & $\begin{array}{l}\text { Blinding not reported. } \\
\text { Prevalent cases }\end{array}$ & $\mathrm{C}$ \\
\hline
\end{tabular}


Table 2 (cont.)

\begin{tabular}{|c|c|c|c|c|c|c|}
\hline Author (year) & Number cases & $\begin{array}{l}\text { Number } \\
\text { controls }\end{array}$ & $\begin{array}{l}\text { Results*: freq infection } \\
\text { and seroprevalence }\end{array}$ & $\begin{array}{l}\text { Results: age at } \\
\text { infection }\end{array}$ & Design issues & Rating \\
\hline Riikonen (1989) [35] & 28 prevalent & 184 & & No difference in age at varicella & $\begin{array}{l}\text { Included cases with } \\
\text { optic neuritis. } \\
\text { Blinding not reported. } \\
\text { Prevalent cases. }\end{array}$ & $\mathrm{C}$ \\
\hline Souberbielle (1990) [26] & 153 incident (most) & 153 & $\begin{array}{l}\text { No difference in varicella frequency, } \\
60.1 \% \text { vs. } 62 \%\end{array}$ & & $\begin{array}{l}\text { Unblinded data collection. } \\
\text { Prevalent cases. }\end{array}$ & $\mathrm{C}$ \\
\hline Bachmann (1998) [36] & 606 prevalent & Entire pop'n & & $\begin{array}{l}81.9 \% \text { MS patients had varicella } \\
\text { at age 5-19 years vs. } 39.0 \% \text { controls }\end{array}$ & $\begin{array}{l}\text { Data collection } \\
\text { not standardized and } \\
\text { unblinded. Prevalent } \\
\text { cases. }\end{array}$ & $\mathrm{C}$ \\
\hline Compston (1986) [27] & $\begin{array}{l}177 \text { incident, } \\
\text { prevalent }\end{array}$ & 164 & No difference in zoster frequency & & $\begin{array}{l}\text { Unblinded data collection. } \\
\text { Only acutely relapsing } \\
\text { patients, and those } \\
\text { with isolated demyelinating } \\
\text { lesions included. }\end{array}$ & $\mathrm{C}$ \\
\hline Lenman (1969) [28] & 50 prevalent & 50 & $\begin{array}{l}\text { No difference in varicella frequency. } \\
\text { Zoster more frequent in cases, } \\
P<0.05\end{array}$ & & $\begin{array}{l}\text { No diagnostic criteria. } \\
\text { Data collection not } \\
\text { standardized and unblinded. } \\
\text { Prevalent cases. }\end{array}$ & $\mathrm{D}$ \\
\hline Ross (1965) [29] & 76 prevalent & 76 & $\begin{array}{l}\text { No difference in varicella or zoster } \\
\text { frequency }\end{array}$ & & $\begin{array}{l}\text { No diagnostic criteria. } \\
\text { Blinding not reported. } \\
\text { Lack of information on } \\
\text { selection of cases. }\end{array}$ & $\mathrm{D}$ \\
\hline Sullivan (1984) [37] & 88 prevalent & 88 & & No difference in age at varicella & $\begin{array}{l}\text { Subjects from previous } \\
\text { cohort for genetic } \\
\text { study and sporadic; } \\
\text { selection poorly described. } \\
\text { Prevalent cases. }\end{array}$ & D \\
\hline
\end{tabular}

* Statistically significant results in bold. 
design as well as a cohort design and therefore counted as two study designs [10].

\section{Frequency of infection}

\section{Case-control studies}

Panelius et al. published two articles with results derived from a single study; thus all results were considered together. This study was rated as ' $\mathrm{C}$ ' $[11$, 12]. The remaining 18 studies included 1 ' $A$ ', 2 ' $B$ ', 12 ' $C$ ', and 3 ' $D$ ' studies [10, 13-29] (Table 2).

The only 'A' study was conducted by the Italian MS Study Group, enrolled incident cases, and assessed past exposure using a questionnaire administered by trained interviewers. No statistically significant difference in the reported frequency of varicella or herpes zoster among cases and controls was detected [13]. The ' $\mathrm{B}$ ' studies of Casetta et al., and Gusev et al. enrolled prevalent cases, used trained interviewers, and had results consistent with those of the Italian MS Study Group for both varicella and herpes zoster infection [14, 15].

The ' $\mathrm{C}$ ' studies used prevalent cases, generally provided less information about the selection process for cases and controls, and either lacked or did not report blinding of exposure ascertainment $[10,11$, 16-26]. None of these studies detected a difference in the reported frequency of varicella. Five of those studies also assessed zoster but again, none detected a difference in the reported frequency of herpes zoster $[11,16,20,23,26]$.

Three of the ' $C$ ' studies assessed only zoster $[10,18$, 19]. Beebe et al. used US Army records to conduct a study of 379 cases and (matched) controls [10]. They neither provided diagnostic criteria for cases, nor described the method of selection for the cases and controls. Assuming that there was no association between zoster and MS, only one-third of a case of zoster would have been expected in each of the case and the control group. Indeed, no zoster was observed in either group. Berr et al. identified an increased frequency of zoster among MS patients $(17.5 \%)$ as compared to controls $(5.3 \%), P<0.05$, but data collection was conducted by one of the investigators who was presumably aware of both the study hypothesis and the disease status of the study subjects [18]. No difference was found in the frequency of varicella infection. Cendrowski et al. found a decreased frequency of zoster, $P<0.01$, but not varicella among cases [19]. In this study the control group was more frequently male and was older. As zoster occurs with increasing frequency with increasing age this discrepancy in the age distribution in the comparison groups may have been responsible, at least in part, for the observed difference in zoster frequency.

Compston et al. ('D') did not detect a difference in zoster frequency [27]. Exposure ascertainment by Compston et al. was not blinded and the case definition included MS cases only if the patients were acutely relapsing, and also included subjects with isolated demyelinating lesions [27]. Ross et al. did not report the diagnostic criteria used, describe the source of the cases, or discuss blinding of exposure ascertainment [29]. They found no difference in the reported frequency of zoster. Lenman et al. found an increased frequency of zoster among MS cases, but this was one of the earliest studies, suffering from the same limitations as Ross et al. [28, 29]. The definition of multiple sclerosis was not clearly described, data collection was not standardized, and the interviewer was not blinded [28].

\section{Historical cohort studies}

There were two historical cohort studies, both 'B' rated [10, 30] (Table 3). Ragazzino and Kurland identified a cohort of 590 patients with zoster by chart review and accumulated 9389 person-years of followup, yet were unable to detect an increased incidence of MS among this group as compared to an expected number calculated from age and sex-specific incidence rates in Rochester, USA [30]. However, this study was underpowered as the authors themselves estimated that 190000 person-years of follow-up would be required in order to detect a threefold increase in MS incidence with a power of $85 \%$. Beebe et al. used the US Veterans' database to assemble a cohort of 636 US veterans hospitalized for zoster [10]. They estimated that in a cohort of this size less than one case of MS would be expected. No cases were observed. Based on these results Beebe et al. concluded that there was no association between zoster and multiple sclerosis, but the sample size was probably too small. Furthermore the diagnostic criteria were not discussed.

\section{Ecological studies}

Ross et al. conducted two ecological studies concerning varicella, one rated ' $A$ ' and the other ' $B$ ' [ 31 , 32]. The ' $A$ ' study examined the association between varicella incidence rates in the 5-14 year age-group, 
Table 3. Historical cohort studies

\begin{tabular}{lllll}
\hline \hline Author (year) & $\begin{array}{l}\text { Cohort } \\
\text { size }\end{array}$ & $\begin{array}{l}\text { Design } \\
\text { issues }\end{array}$ & Results & Rating \\
\hline Ragazzino (1983) [30] & 590 & $\begin{array}{l}\text { Underpowered to } \\
\text { detect a difference } \\
\text { Lacking diagnostic } \\
\text { criteria; possibly } \\
\text { underpowered }\end{array}$ & $\begin{array}{l}\text { No cases of MS } \\
\text { a case; none } \\
\text { observed }\end{array}$ & B \\
\hline \hline
\end{tabular}

and MS case-to-control ratios in the United States [31]. There were positive correlations between mean $(r=0 \cdot 344, P=0.037)$, median $(r=0 \cdot 384, P=0 \cdot 019)$ and maximum $(r=0.301, P=0.07)$ varicella incidence rates and MS ratios, but there were clear outliers in both Arizona and Nebraska. Arizona has a low case-control ratio of MS but a high incidence of varicella, while Nebraska has a high case-control ratio of MS but a low incidence of varicella. The other study compared the incidence rates of MS, zoster and varicella among the Hutterite population of Manitoba, Canada, to those of non-Hutterites matched for age, sex and area of residence [32]. MS, varicella and zoster all occurred significantly less frequently among the Hutterites than would be expected for the Manitoban population as a whole $(P<0.02, P<0.001, P<0.0001$, respectively $)$.

\section{Age at acquisition of infection}

In addition to the reported occurrence of infection several studies also examined the age of infection.

\section{Case-control studies}

Poskanzer et al. published two articles with results derived from a single study; thus all results were considered together and the study rated as ' $\mathrm{C}$ ' $[33$, 34]. Therefore, 2 ' $\mathrm{B}$ ', 5 ' $\mathrm{C}$ ', and 3 ' $\mathrm{D}$ ' studies examined the association between MS and the age at which varicella infection occurred $[14,15,18,21,22$, $25,33,35-37]$. The ' $B$ ' studies did not find a difference in the reported ages of varicella infection $[14,15]$. Casetta et al. [14] and Gusev et al. [15] enrolled prevalent cases and assessed past exposure using questionnaires administered by trained interviewers.

Haile et al. and Berr et al. found non-significant increases in the reported age at which varicella infection occurred among MS patients relative to controls [18, 22]. Prevalent cases were used and questionnaires were administered by one of the investigators. None of the other studies detected a difference $[21,25,33,35]$.

Bachmann ('D') found a shift in the age-atacquisition curve among cases to later age $(P=0 \cdot 01)$ [36]. Bachmann compared retrospectively collected data from cases with prospectively collected population data, likely representing a different cohort. Compston et al. and Sullivan et al. did not detect a difference in the age at varicella infection [27, 37].

\section{Seroprevalence studies}

\section{Case-control studies}

Seroprevalence data were presented in three casecontrol studies all rated as ' $\mathrm{C}$ ' $[23,33,38]$. This group of studies used prevalent cases and generally did not discuss blinding of laboratory procedures. Panelius et al. found an increased prevalence of VZV antibodies and increased titres among MS patients [23]. The other two studies did not find significant differences in either prevalence or titres of VZV antibodies [33, 38]. Two studies, both rated as ' $D$ ', measured titres but not the prevalence of varicella antibodies in serum [27, 29]. Ross et al. found that varicella titres were increased in MS patients $(P<0 \cdot 05)$ [29]. Compston et al. did not detect a difference [27].

\section{Seroepidemiological studies}

Two ' $\mathrm{B}$ ' studies and one ' $\mathrm{C}$ ' study measuring seroprevalence were identified [39-41] (Table 4). These three studies found no difference in the prevalence of VZV antibodies. Seven other studies (3 'B', 4 'C') measured VZV antibody titres in MS patients and comparison groups [42-48]. As a group the seroepidemiological studies provided poorer descriptions of case definitions and of the sources of cases and controls. Several studies also failed to discuss blinding of laboratory investigations. None of the studies rated as ' $\mathrm{B}$ ' detected a difference in VZV antibody titres [42, 47, 48]. Sample sizes were 19-134. 
Table 4. Seroepidemiological studies

\begin{tabular}{|c|c|c|c|c|c|}
\hline Author (year) & $\begin{array}{l}\text { Number } \\
\text { cases }\end{array}$ & $\begin{array}{l}\text { Number } \\
\text { controls }\end{array}$ & $\begin{array}{l}\text { Design } \\
\text { issues }\end{array}$ & Results* & Rating \\
\hline Leinikki (1982) [49] & 18 incident & 120 & & $\begin{array}{l}\text { MS cases: no difference in } \\
\text { seroprevalence; } \\
\text { higher prevalence of CSF } \\
\text { antibodies }\end{array}$ & A \\
\hline Salmi (1974) [51] & 87 prevalent & 101 & & No difference in CSF prevalence & A \\
\hline Bray (1983) [39] & 313 prevalent & 406 & $\begin{array}{l}\text { Poor description } \\
\text { source of subjects }\end{array}$ & No difference in seroprevalence & B \\
\hline Chiodi (1987) [47] & 28 prevalent & 7 & Blinding not reported & $\begin{array}{l}\text { No difference in proportion } \\
\text { with VZV antibodies in serum } \\
\text { or CSF }\end{array}$ & $\mathrm{B}$ \\
\hline Cremer (1980) [48] & 134 prevalent & 165 & Blinding not reported & $\begin{array}{l}\text { No difference in serum VZV } \\
\text { titres or CSF prevalence }\end{array}$ & $\mathrm{B}$ \\
\hline Forghani (1980) [50] & 128 prevalent & 151 & Blinding not reported & $\begin{array}{l}\text { Higher prevalence CSF } \\
\text { antibodies to varicella in cases, } \\
P<0 \cdot 01\end{array}$ & $\mathrm{~B}$ \\
\hline Kinnunen (1990) [42] & 19 prevalent & 19 & Blinding not reported & $\begin{array}{l}\text { No difference in mean serum } \\
\text { antibody titres of VZV }\end{array}$ & B \\
\hline Myhr (1998) [40] & 144 prevalent & 170 & Blinding not reported & $\begin{array}{l}\text { No difference in seroprevalence } \\
\text { of VZV antibodies, } \\
\text { OR }=0.84(P=0.84)\end{array}$ & $\mathrm{B}$ \\
\hline Brody (1971) [45] & 97 prevalent & 100 & & & $\mathrm{C}$ \\
\hline Ito $(1975)[46]$ & 59 prevalent & 267 & $\begin{array}{l}\text { Blinding and diagnostic } \\
\text { criteria not reported }\end{array}$ & $\begin{array}{l}\text { MS cases: mean serum VZV } \\
\text { titres higher vs. all non-MS } \\
\text { except rheumatoid arthritis; CSF } \\
\text { antibody titres to VZV higher }\end{array}$ & $\mathrm{C}$ \\
\hline Nikoskelainen (1972) [43] & 52 prevalent & 91 & $\begin{array}{l}\text { Blinding, source of subjects } \\
\text { and diagnotic criteria } \\
\text { not reported }\end{array}$ & No difference in serum VZV titres & $\mathrm{C}$ \\
\hline Sever (1971) [44] & 106 prevalent & 202 & $\begin{array}{l}\text { Diagnostic criteria } \\
\text { not reported }\end{array}$ & $\begin{array}{l}\text { MS cases: Vermont- higher } \\
\text { serum VZV titres, } P=0 \cdot 025\end{array}$ & $\mathrm{C}$ \\
\hline Vartdal (1980) [41] & 12 prevalent & 12 & $\begin{array}{l}\text { Blinding not reported. } \\
\text { Source of subjects } \\
\text { not reported }\end{array}$ & $\begin{array}{l}\text { MS cases: higher proportion with } \\
\text { evidence intrathecal antibody } \\
\text { synthesis }\end{array}$ & $\mathrm{C}$ \\
\hline
\end{tabular}

* Statistically significant results in bold. 
The ' $C$ ' studies had variable results [43-47]. Sever et al. found that VZV titres were increased in the MS patients at only one of the three study sites (Vermont) [44]. Ito et al. also found that MS patients had higher titres, but Nikoskelainen et al. and Brody et al. did not $[43,45,46]$. Only Brody et al. discussed blinding of laboratory procedures [43-47].

\section{CSF antibody studies}

\section{Seroepidemiological studies}

Four studies examined the prevalence of VZV antibody in CSF [48-51]. Cremer et al. had also measured serum antibodies as noted above. The two studies rated as 'A' produced inconsistent results. Leinikki et al. found that a higher proportion of MS patients had VZV antibodies, but Salmi et al. did not [49, 51]. Similarly, the 'B' studies had conflicting results [48, 50]. Neither study discussed blinding of laboratory procedures.

One ' $\mathrm{B}$ ' and one ' $\mathrm{C}$ ' study compared VZV titres in CSF $[46,47]$. No difference was detected by Chiodi et al. [47]. Twenty-eight prevalent cases with clinically definite MS were enrolled along with seven controls. However, the diagnostic criteria used were not indicated, nor were the source(s) of the cases and controls. Ito et al. found that titres were significantly increased among MS patients in their study [46]. This study also did not report the diagnostic criteria used for MS and blinding was not discussed.

\section{DISCUSSION}

Our search strategy evaluated only the English language medical literature. Important studies published in other languages could have been missed. The failure to contact experts in the field for studies may have missed unpublished studies. Due to publication bias these may have been more likely to be negative studies. The use of both electronic and hand searching should have minimized the number of studies written in the English language which were missed. All the studies identified, except case series, case reports and reviews were included in the study as we wanted a broad view of the literature available. The data available in most studies, however, were insufficient to allow a pooling of the results for a formal metaanalysis.

There is geographical and temporal variation in MS incidence rates, and there is an apparent change in disease risk associated with migration between areas with differing risks of MS, depending upon the age at migration [2]. Migration studies have been interpreted to indicate the importance of exposure to an environmental factor in early life between the ages of 10 and 15 years [2]. This has led to hypotheses that infections are aetiological factors in MS and that timing of these exposures is important.

The aetiological role of VZV infection in the development of MS has been examined in seroepidemiological, historical cohort, case-control and ecological studies. Cohort studies provide a strong level of observational evidence. These studies have the advantage of establishing exposure without the bias of already knowing the disease outcome. Case-control studies can also provide a strong level of evidence. These studies are strongest if incident cases are used, thus avoiding the risk of selective survivor biases and reducing the impact of recall bias. Ecological studies provide very weak epidemiological evidence. In these latter studies the average exposure of the population to a risk factor in the environment is examined. An individual classified in the exposed group may not actually share the exposure of the group, and there may be unidentified counfounding factors. These studies are best regarded as hypothesis generating. Seroepidemiological studies document evidence of prior infection but cannot establish when an infection occurred, its severity or even whether it was clinically symptomatic or asymptomatic. These studies are more appropriate for generating than testing hypotheses of risk. Ideally well-designed studies of each type would provide a consistent association. These weaker studies were included in order to see if there was such a consistent association throughout the literature.

In our evaluation of the epidemiological evidence, two historical cohort studies failed to detect a difference in the frequency of varicella infection between subjects with and without MS, however both were probably underpowered to detect a difference. The case-control studies reviewed consistently failed to show an association. The case-control studies with the strongest methodologies also failed to show an increased frequency of zoster among MS patients. Among the nine studies assessing age at infection, only the study with the weakest methodology found a significant difference. The seroepidemiological studies produced inconsistent and unconvincing results. Ecological studies provided the only evidence to support an aetiological role for varicella in multiple sclerosis but these studies are of minimal importance. At the 
present time the epidemiological evidence is insufficient to support an aetiologic role of VZV infection in the development of MS.

Varicella zoster virus infection may be one of many factors causing $\mathrm{MS}$ in a genetically susceptible individual and may be neither a necessary nor a sufficient cause [52]. Exposure is likely to be highly prevalent among persons with and without MS, requiring large sample sizes to identify an effect. MS is relatively rare, probably with a long latency between exposure and symptom onset, making it difficult to verify the temporal relationship between exposure and disease onset. Future analytical studies should use large numbers of incident cases with blinded, trained interviewers using confirmatory sources for recalled data.

\section{REFERENCES}

1. Granieri E. The epidemiologic study of exogenous factors in the etiology of multiple sclerosis. Neurology 1997; 49 (Suppl. 2): S2-3.

2. Weinshenker BG. Epidemiology of multiple sclerosis. Neurol Clin 1996; 14: 291-308.

3. Brankin B. Viruses in multiple sclerosis models. Int MSJ 1995; 2: 51-9.

4. Picard FJ, Poland SD, Rice GPA. New developments with herpes viruses and the nervous system. Curr Opin Neurol Neurosurg 1993; 6: 169-75.

5. Barnes DW, Whitley RJ. CNS diseases associated with varicella zoster virus and herpes simplex virus infection. Pathogenesis and current therapy. Neurol Clin 1986; 4 : 265-83.

6. Tenser RB. Herpes simplex and herpes zoster. Nervous system involvement. Neurol Clin 1984; 2: 215-40.

7. Wolfson C, Granieri E, Lauer K. Case-control studies in multiple sclerosis. Neurology 1997; 49 (Suppl. 2): S5-14.

8. Riise T. Historical cohort studies in multiple sclerosis. Neurology 1997; 49 (Suppl. 2): S15-7.

9. Lauer K. Ecologic studies of multiple sclerosis. Neurology 1997; 49 (Suppl. 2): S18-26.

10. Beebe GW, Kurtzke JF. Herpes zoster and multiple sclerosis. BMJ 1969; 4: 303.

11. Panelius M. Studies on epidemiological, clinical and etiological aspects of multiple sclerosis. Acta Neurol Scand 1969; Suppl 39: 1-82.

12. Panelius M, Rinne UK, Kivalo E. Association between the geographic distributions of multiple sclerosis and some infections in Finland. Europ Neurol 1970; 4: 22-30.

13. Italian Multiple Sclerosis Study Group. Migration and infectious diseases in the etiology of multiple sclerosis: a case-control study. In: Battaglia MA, ed. Multiple sclerosis research. Amsterdam: Excerpta Medica,
Elsevier Science Publishers B. B. (Biomedical Division), 1989: 147-58.

14. Casetta I, Granieri E, Malagu S, et al. Environmental risk factors and multiple sclerosis: a community-based, case-control study in the province of Ferrara, Italy. Neuroepidemiol 1994; 13: 120-8.

15. Gusev E, Boiko A, Lauer K, Riise T, Deomina T. Environmental risk factors in MS : a case-control study in Moscow. Acta Neurol Scand 1996; 94: 386-94.

16. Alter M, Speer J. Clinical evaluation of possible etiologic factors in multiple sclerosis. Neurology 1968; 18: 109-16.

17. Bansil S, Singhal BS, Ahuja GK, et al. Multiple sclerosis in India: a case-control study of environmental exposures. Acta Neurol Scand 1997; 95: 90-5.

18. Berr C, Puel J, Clanet M, Ruidavets JB, Mas JL, Alperovitch A. Risk factors in multiple sclerosis: a population-based case-control study in HautesPyrenees, France. Acta Neurol Scand $1989 ;$ 80 : 46-50.

19. Cendrowski W, Wender M, Dominik W, Flejsierowicz Z, Owsianowksi M, Popiel M. Epidemiological study of multiple sclerosis in western Poland. Eur Neurol 1969; 2: 90-108.

20. Currier RD, Martin EA, Woosley PC. Prior events in multiple sclerosis. Neurology 1974; 24: 748-54.

21. Gronning M, Riise T, Kvale G, Albrektsen G, Midgard $\mathrm{R}$, Nyland H. Infections in childhood and adolescence in multiple sclerosis. A case-control study. Neuroepidemiol 1993; 12: 61-9.

22. Haile RT, Smith P, Read D, Nassim D, Warlow C, Russell WC. A study of measles virus and canine distemper virus antibodies, and of childhood infections in multiple sclerosis patients and controls. J Neurol Sci 1982; 56: 1-10.

23. Panelius M, Salmi A, Holene PE, Kivalo E, Rinne UK, Penttinen K. Virus antibodies in serum specimens from patients with multiple sclerosis, from siblings, and matched controls. A final report. Acta Neurol Scand 1973; 49: 85-107.

24. Hopkins RS, Indian RW, Pinnow E, Conomy J. Multiple sclerosis in Galion, Ohio: prevalence and results of a case-control study. Neuroepidemiol 1991; 10: $192-9$.

25. Kurtzke JF, Hyllested K, Arbuckle JD, et al. Multiple sclerosis in the Faroe Islands. 7. Results of a case control questionnaire with multiple controls. Acta Neurol Scand 1997; 96: 149-57.

26. Souberbielle BE, Marin-Mondiere C, O'Brien ME, Carydakis C, Cesaro P, Degos JD. A case-control epidemiological study of MS in the Paris area with particular reference to past disease history and profession. Acta Neurol Scand 1990; 82 : 303-10.

27. Compston DAS, Vakarelis BN, Paul E, McDonald WI, Batchelor JR, Mims CA. Viral infection in patients with multiple sclerosis and HLA-DR matched controls. Brain 1986; 109: 325-44.

28. Lenman JAR, Peters TJ. Herpes zoster and multiple sclerosis. BMJ 1969; 2: 218-20.

29. Ross CAC, Lenman JAR, Rutter C. Infective agents and multiple sclerosis. BMJ 1965; 1: 226-9. 
30. Ragozzino MW, Kurland LT. Epidemiologic investigation of the association between herpes zoster and multiple sclerosis. Neurology 1983; 33: 648-9.

31. Ross RT, Cheang M. Geographic similarities between varicella and multiple sclerosis: an hypothesis on the environmental factor of multiple sclerosis. J Clin Epidemiol 1995; 48: 731-7.

32. Ross RT, Nicolle LE, Cheang M. Varicella zoster virus and multiple sclerosis in a Hutterite population. J Clin Epidemiol 1995; 48: 1319-24.

33. Poskanzer DC, Sheridan JL, Prenney LB, Walker AM. Multiple sclerosis in the Orkney and Shetland Islands ii: the search for an exogenous aetiology. J Epidemiol Community Hlth 1980; 34: 240-52.

34. Poskanzer DC, Sever JL, Sheridan JL, Prenney LB. Multiple sclerosis in the Orkney and Shetland Islands iv: viral antibody titres and viral infections. J Epidemiol Commun Hlth 1980; 34: 258-64.

35. Riikonen $\mathrm{R}$. The role of infection and vaccination in the genesis of optic neuritis and multiple sclerosis in children. Acta Neurol Scand 1989; 80: 425-31.

36. Bachmann S, Kesselring J. Multiple sclerosis and infectious childhood diseases. Neuroepidemiol 1998; 17: $154-60$.

37. Sullivan CB, Visscher BR, Detels R. Multiple sclerosis and age at exposure to childhood diseases and animals: cases and their friends. Neurology $1984 ; 34$ : 1144-8.

38. Gudmundsdottir S. Multiple sclerosis and common viral infections in Iceland. Acta Path Microbiol Scan Sect B 1979; 87: 379-84.

39. Bray PF, Bloomer LC, Salmon VC, Bagley MH, Larsen PD. Epstein-Barr virus infection and antibody synthesis in patients with multiple sclerosis. Arch Neurol 1983; 40: 406-8.

40. Myhr K-M, Riise T, Barrett-Connor E, et al. Altered antibody pattern to Epstein-Barr virus but not to other herpesviruses in multiple sclerosis: a population based case-control study from western Norway. J Neurol Neurosurg Psychiatry 1998; 64: 539-42.
41. Vartdal F, Vandvik B, Norrby E. Viral and bacterial antibody responses in multiple sclerosis. Ann Neurol $1980 ; 8$ : $248-55$.

42. Kinnunen E, Valle M, Piirainen L, et al. Viral antibodies in multiple sclerosis: a nationwide co-twin study. Arch Neurol 1990; 47: 743-6.

43. Nikoskelainen J, Panelius M, Salmi A. E.B. virus and multiple sclerosis. BMJ 1972; 4: 111.

44. Sever JL, Kurtzke JG, Alter M, et al. Virus antibodies and multiple sclerosis. Arch Neurol 1971; 24: 489-94.

45. Brody JA, Sever JL, Henson TE. Virus antibody titers in multiple sclerosis patients, siblings, and controls. JAMA 1971; 216: 1441-6.

46. Ito $\mathrm{M}$, Barron AL, Olszewski WA, Milgrom F. Antibody titers by mixed agglutination to varicellazoster, herpes simplex and vaccinia viruses in patients with multiple sclerosis. Proc Soc Exper Biol Med 1975; 149: 835-9.

47. Chiodi F, Sunqvist, Link H, Norrby E. Viral IgM antibodies in serum and cerebrospinal fluid in patients with multiple sclerosis and controls. Acta Neurol Scand 1987; 75: 201-8.

48. Cremer NE, Johnson KP, Fein G, Likosky WH. Comprehensive viral immunology of multiple sclerosis II. Analysis of serum and CSF antibodies by standard serologic methods. Arch Neurol 1980; 37: 610-5.

49. Leinikki P, Shekarchi I, Iivanainen M, et al. Virus antibodies in the cerebrospinal fluid of multiple sclerosis patients detected with ELISA tests. J Neurol Sci 1982; 57: 249-55.

50. Forghani B, Cremer NE, Johnson KP, Fein G, Likosky WH. Comprehensive viral immunology of multiple sclerosis III. Analysis of CSF antibodies by radioimmunoassay. Arch Neurol 1980; 37: 616-9.

51. Salmi A, Panelius M, Vainionpaa R. Antibodies against different viral antigens in cerebrospinal fluid of patients with multiple sclerosis and other neurological diseases. Acta Neurol Scand 1974; 50: 183-93.

52. Rothman KJ. Causes. Am J Epidemiol 1976; 104: 587-92. 